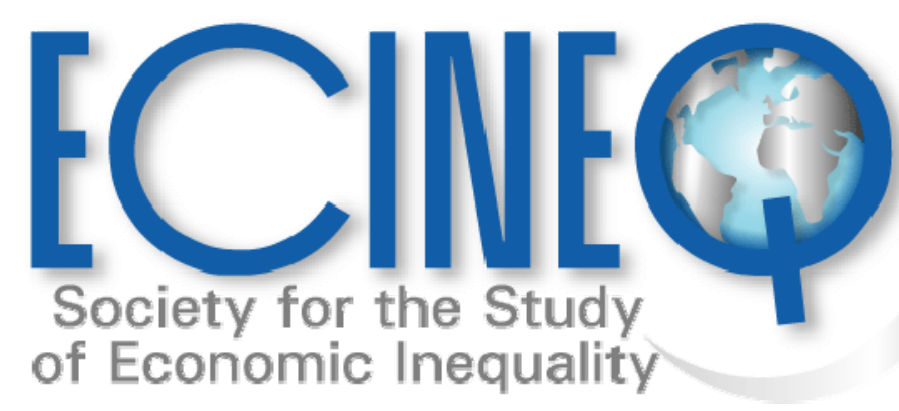

Working Paper Series

The Economic Thought on Poverty Measurement: From the NineteenthCentury to the Rediscovering Era

Celso Nunes 


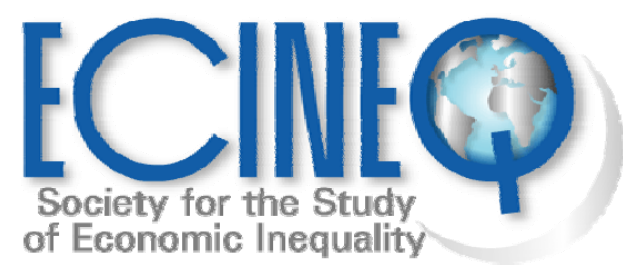

ECINEQ 2008-92

August 2008

www.ecineq.org

\title{
The Economic Thought on Poverty Measurement: From the Nineteenth-Century to the Rediscovering Era
}

\author{
Celso Nunes* \\ Madeira University
}

\begin{abstract}
This essay describes the evolution of the Economics of Poverty from the seminal works of Charles Booth and Joseph Rowntree to the Rediscovering Era in the 1960's. It shows how the leading objectives of its authors changed over the decades. The description is roughly exhaustive, pointing out the way how the leading concepts, many of them frequently used even nowadays, were developed by its authors.
\end{abstract}

Key words: approaches, poverty measurement, techniques

JEL Classification: B49, I32

\footnotetext{
* Address of correspondence: Celso Nunes, Departamento de Gestão e Economia, Universidade da Madeira, Caminho da Penteada 9020-105 Funchal Portugal. E-mail: clpnunes@uma.pt .
} 


\section{Introduction}

Poverty measurement is one of the most crucial developments in economics since the concepts of poverty and poverty alleviation are perennial questions that governments and scholars continuously discuss. From simple household surveys in the nineteenth-century to the complex research design models today to create new indicators and variables of poverty, the literature has gone a long way towards developing a scientific approach to the problem.

In this paper, the economic literature on poverty is exhaustively discussed starting with the preliminary works of Charles Booth and Benjamin Rowntree up to the Rediscovering Era with Peter Townsend and the American Economists of the 1960's. In Section II, major works written about poverty in the transition from the nineteenth- to the twentieth-century are presented. This period, characterized by the development of poverty surveys in Britain, covers the works of Charles Booth and Benjamin Rowntree. In Section III, the rediscovery of poverty era is described and commented. Some concluding remarks on the evolution of the leading objectives of the authors in the final section try to point out the idea that these objectives varied a lot. 


\section{The Roots of the Economic Thought on Poverty}

The author of the very first paper written and published specifically about poverty was Charles Booth. Before becoming a well-respected statistician and scholar on poverty in London, he worked in a shipping company and set up a business where he learned the foundations of business methods. This became a good basis of the methodology that he would apply in his approach to social investigation. As a matter of fact, in business as in social investigation, Booth not only had appreciation for rigorous descriptions of the reality in facts and figures, he also believed that this was essential for success - whether in business or in the fight against poverty. His social life and friendships - when he was in his forties living in London - created the environment in which he could discuss social problems. As a growing city of enormous economic importance, London focused the attention on poverty. During this period, social science was yet to develop systematic methods in its analysis and rigor over press reports about poverty. In his seminal book Life and Labour of the People in London (Booth 1903), he attempted to uncover and explain the nature, conditions, and trends in poverty by looking at the working and living situations of people in London from 1886 to 1903. Using his own money, he gathered responses through a massive survey of approximately 120,000 respondents, which include household individuals, 
employers, trade union officials, workers, administrators, clergy, and those engaged in social and charitable activities. Its major contribution includes the following: the classification of the people according to the means and position of the heads of families and to the character of their employment; the trade inquiries to show the conditions under which people work; and the district inquiries to show the conditions under which they live (Booth 1887). This seventeen-volume work is the culmination of his career as a social scientist on poverty and it remains to be one of the first scientific social surveys of London.

In his previous works (Booth 1887, 1888), he contributed in understanding and measuring poverty through an exhaustive classification of people based on their social conditions. The object of these works is to «show the conditions under which the people live, but it would also give their employments; the principal object of the trade inquiry would be to show the conditions under which the people work, but it would indirectly deal with their manner of life» (Booth 1887: 326). Although the paper cannot be considered a crucial development in statistical methodology, the comprehensive and detailed descriptions of the different work types, their incomes, and their purchasing power relative to the prices all contribute in the development of systematization of defining who the poor are. More importantly, the method employs dual classification based on occupation and section to define a poverty line thereby classifying certain job types as "poor" 
and "very poor". Poor is defined as «those who have a fairly regular though bare income, such as 18 s. to 21 s. per week for a moderate family» while very poor are «those who fall below this standard, whether from chronic irregularity of work, sickness, or a large number of young children» (Booth 1888: 328). This is shown in Table 1.

Using a double classification, he sought to find out the extent of poverty by knowing how many are very poor, the poor or the well to do. This allowed him to infer something of the poverty-inducing conditions that prevail in British society (Warner 1889, 1894). His major finding was a breakaway from the common perceptions on poverty: while most scholars thought poverty was concentrated in Tower Hamlets (East London), he showed that it was in the districts of Waterloo, St. Saviour's, and Bermondsey (South). It raised the need for a systematic examination on the causes and conditions of poverty (Abbott 1917; Booth 1887, 1888). As a matter fact, Booth's work is very important to the history of poverty measurement not only due to his pioneering effort to measure poverty, but also to his conviction - put in practice in the study of social conditions, including poverty - that a truly grounded description in facts and figures of social situations is important to succeed. Finally, he also contributed in the social scientific inquiry of distinguishing poverty from unhappiness, thereby alerting 
social economists and other social scientists from the grave mistake of treating both as the same.

General Francis Amasa Walker, a prominent figure in the second half of the nineteenth-century in American Economics, would be the author of the first paper on the economic nature of poverty, written without any political or merely social motivation. He was the first president of the American Economic Association, the first lecturer on Economics at Johns Hopkins, one of the first presidents of the Massachusetts Institute of Technology, president of the American Statistical Association, head of the statistical bureau of the U. S. Treasury, professor at Yale University and he would award the "Walker Medal” to leading Economists for lifetime achievements. His theory of distribution, inspired and developed from the "Ricardian" theory of rent, has come to be known as the residual theory.

Though not familiar with much of the newer literature in Economics, Walker possessed a powerful intellect and was very welcoming to the newer ideas. All through his life, Walker struggled to set up the scientific status of Economics and was a pioneer in using statistical data to illustrate economic arguments. In the last year of his life, his seminal work on the search of the causes of poverty (Walker 1897) was very interesting both from an economic and social scientific point of view. In this work, he distinguished poverty from pauperism, 
explaining the causes of the latter concept. In doing so, he successfully criticized the shortcomings of existing explanations on poverty ranging from the theological to the socialist views. His basic thrust is that «all only-one-cause explanations are not sufficient to explain poverty» (Walker 1897). He proposed four basic explanations for poverty: (1) the naturally difficult, established conditions of the humankind; (2) a secondary poverty which results from industrialization (for instance, the division of labor forcing certain people to take low wage jobs under severe working and living conditions); (3) the existence of the great law "For unto every one that hath shall be given, and he shall have abundance: but from him that hath not, even that which he hath shall be taken away"; and (4) finally, the carelessness, lack of frugality and bad habits on the part of the working classes. To fight against the poverty, Walker suggests the treatment of mental and moral disease as well as a bigger sensibility for popular education.

We cannot be assured of what moved Walker in writing this article. Certainly it was not written for academic reasons, but it is difficult to understand if his main objective would be to give a pure contribution to the understanding of the causes of poverty or a response to the temptation of the religious and the socialists to take over economics for them. In this way, he participated in the fight to recognize Economics as a scientific subject. Very likely he condensed the two objectives in one article, as a parallel for other articles in other branches of 
Economics. However, his major flaw is that his "economic reasons" were not justified on scientific grounds but rather only with opinion-based arguments, not using a very refined method.

At the turn of the century, two authors brought out contributions about poverty: Dadabhai Naoroji and Benjamin Rowntree. Naoroji's contribution is the so-called drain theory, which attempts to explain the "pitiless drain" of India's resources to England during the colonial period. He was the author of one of the first books written to raise nationalist sentiments (Naoroji 1901). He argues that the "drain of wealth”, or the unilateral transfer of resources from India to Britain, was the principal cause of poverty in India, such as when Britain puts the average tax burden in India at twice that of contemporary England, although average income there was fifteen times greater at that point in time. During the first decade of the twentieth-century he was prominent in several Socialist International Congresses speaking on matters related to colonial exploitation and workers in the industrialized world. Clearly, his reasons to write about poverty were merely nationalist and political. More importantly, his attribution of poverty is on external factors without any systematic reflection on the internal problems of India. This is essential since his theory seems to be economically unsound if compared to the development of theories on classical political economy. The theory resembles several similarities with the dependency school in the field of 
political economy, such as the exploitative nature of external capitalist forces (primarily the colonial power) and the unequal global structure leading to systematic poverty. Hence, Naoroji's work is important in contributing to the literature of political economy rather than the development of economics and poverty measurement.

Benjamin Seebohm Rowntree was the most influential economist on poverty in the turn of the twentieth-century. Inspired by the work of Charles Booth, and of his own father, Joseph Rowntree, he got on a long investigation of poverty which would become the content of the book "Poverty: A Study of Town Life” (Rowntree, 1901). In this book, he uses research methods that, although in a very different circumstance, still have validity today. His investigation was applied to his native city of York, based on his house to house survey in this city. In the beginning of Chapter IV - The Poverty Line - when he tries to answer to the question of what proportion of the population is living in poverty, Rowntree proposes two technical definitions of poverty, distinguishing between primary and secondary poverty. Families living in primary poverty are those «whose total earnings are insufficient to obtain the minimum necessaries for the maintenance of merely physical efficiency» (ibidem, p. 86), while in secondary poverty are those «whose total earnings would be sufficient for the maintenance of merely physical efficiency were it not that some portion of it is absorbed by other 
expenditure, either useful or wasteful» (ibidem, pp. 86-87). As a matter fact, his work replicates the objectives and methods of Booth to come up with a more precise definition of poverty line. Rowntree derived the poverty line using the minimum necessary expenditure for the maintenance of physical health. This derivation was computed in 3 steps:

1. To choose the nutritional dietary requirements and the costs of obtaining them on a weekly basis. Here, he used the cheapest rations set by the Local Government Board (3s. gd. for a man, 2s. gd. for a woman, and 2s. gd. for a child) with protein as the basic component of adequate food supplement;

2. To calculate the minimum necessary for clothes, fuel, and other sundries (£4 11d. per week for a family of five);

3. To compute for the total earnings of the family to maintain mere physical efficiency.

So, according to his definitions of poverty, the poverty line became clearer: those families with insufficient earnings to maintain this base line are considered living in primary poverty, while those who have sufficient earnings but with some portion of it being absorbed by other expenditure are defined as living in secondary poverty. His findings show that nearly $10 \%$ of the population of York is living in primary poverty, while $18 \%$ is living in secondary poverty. Overall, his goal was to generate information that will show the «general 
characteristics of York, the social and economic condition of the wage-earning class, the standard of life, including careful studies of the working people divided into several classes, and concerning the poverty line, showing the point below which people were unable to obtain enough to give physical efficiency» (Hunter 1902: 159).

Methodological issues emerged from the study. First, in the face of making a conceptual distinction between primary and secondary poverty, Rowntree maintained that both concepts were of a subjective nature. Primary poverty is subjective since the point at which primary passes into secondary poverty is largely a matter of opinion, depending on the standard of well-being that is considered necessary, and secondary poverty as it obviously depended on the standard of lifestyle held satisfactory by the investigators. Second, Rowntree, who popularized the concept of poverty line, derived it as an heuristic device rather than a normative one prescribing planned patterns of expenditure - to show that, contrary to beliefs held at least since Francis Walker, not only carelessness and vice but also low incomes, accounted for the poverty of the working classes. This meant a deviation from the popular perception of deriving poverty measurement during this time.

Rowntree and his colleagues made a second and third survey in York to show that poverty was almost disappearing in England. The second survey was 
conducted in 1936, which would come out in his book "The Human Needs of Labour” and the third survey in 1951 together with G. R. Lavers which would be entitled "Poverty and the Welfare State". ${ }^{1}$ In his second book, he developed and refined his poverty line in York at a time when a national poverty line was being developed. This so-called "human needs" standards have six basic requirements for a household: food, rent, clothing, fuel and light, household sundries, and personal sundries. In his dietary requirement, he states that

«A man of normal stature engaged in work of moderate severity, required, if health and working capacity were to be maintained, a diet which provided 3,400 calories of fuel energy. It should comprise 100 grams (nearly 4 oz.) of protein and about 100 grams of fat (preferably of animal origin)» (Rowntree 1937: 113).

In Table 2, the summary of the 1936 poverty line is shown. It is essential to point out that some elements of inexactness were introduced to establish minimum wages. In the early 1950s, Lavers and Rowntree published the third social survey to compare the changes in poverty throughout the interwar period. Following the basic design of the 1899 and 1936 surveys, they found out that $4.6 \%$ of working class households $(2.8 \%$ of individuals) were in poverty compared with $31.1 \%$ (of households or individuals) in 1936. This basically became the basis of the so-called "absence of poverty". More specifically, their

\footnotetext{
${ }^{1}$ The discussion here relied heavily on the analysis of Hatton and Bailey (1998 and 2000).
} 
research aimed to establish the effect of the Beveridge reforms (welfare state) on alleviating poverty in England. In comparison, the definition of a working class in 1936 is not more than $£ 250$ per annum and not more than $£ 550$ per annum in 1950. The claims of those who support that the Beveridge reforms are effective do use the Rowntree and Lavers (1951) study. Hence, after Rowntree, poverty would not be a major issue for more than half-century.

Several methodological issues were raised to question the absence of poverty in the interwar years in Britain. There are problems with respect to (1) the reliability of the survey, (2) the representativeness of York in comparison with other towns, and (3) the compatibility of the 1950 poverty line with the 1936 poverty line (Hatton and Bailey 1998, 2000; Townsend 1954, 1962: 211-215). However, its major strength is the accuracy of specific data that were gathered, such as the rent paid and the earnings of working class populations. In effect, Rowntree's contribution is enormous with respect to the systematic social survey on poverty as it moved beyond the limitations of the study of Booth. 


\section{Rediscovering Poverty}

The disappearance of poverty in the discourse of Economics during the first half of the twentieth-century can be attributed to three things. First, there is full employment, including combined with larger real wages and the dramatic increase of married women in the labor sector (paid employment); both brought prosperity to the general population. Second, there has been a marked redistribution of income from rich to poor and, indeed, a continuing equalization of income and wealth. Finally, the introduction of a welfare state has created a net - though some prefer to use the metaphor "feather bed” - which prevents nearly all those who are sick, disabled, old or unemployed from falling below a civilized standard of subsistence (Townsend 1962: 210). The question of poverty was raised again by Peter Townsend, who questioned not only the status of poverty measurement but also whether the 1930s to 1950s indeed had very low poverty rates. Starting from Rowntree, his work was the first systematic endeavor towards a more precise and accurate poverty line. Unlike Booth and Rowntree who used sociological approaches in defining the poor, Townsend suggests selecting, from all those households that satisfy nutritional requirements, the quarter of households that do so at the lowest level of income, and to take total average 
expenditure per household in this group (less some fixed costs), as the poverty line.

In his book Poverty in the United Kingdom, he reports the planned survey he made to over 3,000 households (10,000 individuals) using a 35-page questionnaire. This is the first attempt to respond to various issues in conducting survey research: interviewing, representation, response rates and sampling, among others. In this work, he pioneered the concept of "relative poverty" as opposed to "absolute poverty". ${ }^{2}$ Poverty is not simply the lack of income but also the «lack of resources to participate in a society - resources that stem from a variety of resource distribution systems operating in the society» (Vogel 1982). He criticizes Rowntree for the inadequacy of using mere physical requirements for sufficiency because there is some relativity involved when it comes to diet based on availability, prices and even psychological conditioning (Townsend 1962: 218). In his alternative approach, he challenges the notion of subsistence as a definition and measure of poverty. First, he established the relative connection between levels of income and levels of nutrition. Instead of merely looking at the nutritional requirements for a family and how many fell to meet this income level, it is better to make a random sampling in the population to know how many

\footnotetext{
${ }^{2}$ See (Sen, 1985) and (Townsend, 1985) for a discussion of the debate on relative and absolute approaches to poverty.
} 
families with particular income levels are not able to meet certain level of nutrition. Hence, he posits that there are various levels of nutrition that families attempt to secure at a particular bracket of income. Second, he argues that standards of living also vary among the working populations, such that individuals who earn more tend to have a higher living expenditure compared to the unemployed or the retired people. Third, poverty could be defined on the basis of the number of households or families of certain types having a total income of less than, say, half or two-thirds of the average. This means that more sensitive indicators to standards of living are needed to be developed to properly define poverty. He suggests the use of 'average disposable income per head' or 'average household income' for the income levels of different households. Fourth, he poses that poverty is not always a function of income but also the distribution of nonmonetary resources among individuals and households. Discrepancies over housing, education and medicine and welfare are some of the resources that might affect the definition of poverty. Whether these resources are public or private likewise interferes in measuring the extent of poverty experienced. Finally, Townsend seeks to expand the studies of poverty beyond Great Britain. This is especially important in the context of the decolonization (the increase in number of nation-states becoming independent) where poverty in the so-called Third World would be different from Europe. He sought to take into account the 
inequitable distribution of resources at the international level not only to draw some comparisons but also to systematically analyze poverty in a general sense. In developing indicators for poverty, he suggests the following procedures: (i) collection of data relating to the food consumption and expenditure as well as the income of working-class households; (ii) the comparison of this data, assembled according to constitution of household and income group, with a scale of nutritive needs, such as that in the Report of the Committee on Nutrition of the British Medical Association, 1950; and (iii) the isolation, from all those securing minimum nutrition, of, say, the 25 per cent in the various household groups who achieve it on the smallest incomes, or rather, the smallest incomes less one or two fixed involuntary overheads, such as rent and compulsory insurances. The average total expenditure of these households, less the overheads, according to their different sizes, can be taken as the poverty line. Overall, he concludes by arguing for the creation of a general theory:

«Our general theory, then, should be that individuals and families whose resources, over time, fall seriously short of the resources commanded by the average individual or family in the community in which they live, whether that community is a local, national or international one, are in poverty» (Townsend 1962: 225). 
Nonetheless, the "rediscovery" of poverty would really begin with a series of American empirical studies in the 1960s. Harrington's The Other America (1962) would be the first significant book on the issue. Born in St. Louis, Harrington was educated by the Jesuits at St. Louis University High School. In later life he was sensitive to the resemblance between the Thomistic scholasticism in which he was trained and the Marxist scholasticism that he embraced as an adult. He would admit his influences: "I have long thought that my Jesuit education predisposed me to the worst and best of Marx's thought.” The Other America, a moving portrait of the poor in rural and urban America, is not only a simple descriptive book about poverty, but also a critic for what he believed was an implicit policy of hiding poverty in America and for the consequent unimportance given to the avoidable distress of the poor: «Clothes make the poor invisible, America has the best-dressed poverty the world has ever known» or «If there is a technological advance without a social advance, there is, almost automatically, an increase in human misery» are examples of sentences that illustrate Harrington’s ideas.

Two years after “The Other America”, W. Anderson wrote another major work about the poverty in America entitled Trickling Down (Anderson 1964). In the context of an ever-growing economy, his original ideas were to question if 
economic growth is necessarily poor-favorable and if there is indeed a trickledown effect, which is the dispersion of economic gains from the rich to the poor. In his article, Anderson tries to measure the variations in the strength of the trickle-down effect by connecting economic growth with the rightward movement of a lognormal income distribution. He finds that the poverty reduction effect of growth increases with growth, albeit it should increase at a decreasing rate because of the non-linear tail effects of the distribution of income. This suggests that the poverty reduction effect of high growth may take place partly in the course of inequality reduction effects. Economic growth helps to ease poverty in two ways: (1) as economic growth occurs, the number of jobs will automatically increase due to higher labor demands; and (2) growth creates an upward push in the real wages paid to the workers. Empirical cases have proven this through the analysis of the steady increase in income growth and wages in industrialized and industrializing economies. Even though growth first and foremost benefits those in the upper portions of the income distribution, sufficiently robust growth benefit even those in the lower portions. The idea is that a sufficiently large growth rate has a more than proportional effect on the poverty rate. However, he also points out that the increase in average income is accompanied by income dispersion, which is why poverty incidence still increases as growth occurs. Hence, public 
policies designed to redistribute income or earning power are necessary to reduce the persistence of poverty (Anderson 1964: 513).

His contribution in poverty measurement is at best the concept of poverty incidence curve, which he refers to as «the curve defining the proportion of families in the United States with incomes below $\$ 3000$ as a function of the log of median income for the period 1947-60» (Anderson 1964: 514). The curve is divided into three phases, with subgroups in Phase 1 experiencing high poverty incidence and low income, Phase 2 with relatively equal level of income and poverty incidence, and Phase 3 with high levels of median income and low levels of poverty incidence. In his study, he divided the population into subgroups - such as rural-urban and white-non-white groups - and used the data on median income and poverty incidence. By treating each subgroup with their own median income and poverty incidence, he found out that non-farmer white majority has entered Phase 3 (meaning poverty drops as median income increases) and that most subgroups in Phases 1 and 2 were excluded from the growth process. Other findings include:

- $\quad$ Age is a disadvantage for families headed by males but not for those headed by females. 
- $\quad$ Among the aged, it is not additionally disadvantageous for the head to be a female; it is among the young that this matters.

- $\quad$ The largest differences among families headed by a male under 65 are found between white and non-white farmers, and between farm and non-farm nonwhites (Anderson 1964: 520).

His conclusion based on the movements along the poverty curve is supportive of a poverty program designed to change the existing income distribution and reduce the rate of poverty to any median population income.

Another American empirical work would come up in 1964, but with a focus on social mobility. Stephan Thernstrom, a professor of History at Harvard University, created a thorough portrait of working class life in Newburyport from 1850 to 1880 - the decisive years in which this old Massachusetts town changed into a thriving industrial city (Thernstrom 1964). Thernstrom was aware of the usefulness of data linking individuals across censuses, but lacked the resources to create such data. As a consequence, supported by census reports, local records and newspapers, he traced the career patterns of hundreds of manual workers and their sons over this period, exploring in detail the differing mobility patterns of nativeborn and Irish immigrant workmen. His book Poverty and Progress suggests that when the family strategies function well, the economic security of parents is 
practically based upon the children's sacrifice in the form of private taxation on earnings and lost opportunity for human capital accumulation.

\section{Conclusion}

In the beginning, the leading objectives of the authors that studied poverty varied from one to another. Booth had social concerns, Walker wanted to defend Economics as a science, Naoroji had political and nationalist objectives, and Rowntree had scientific concerns.

With the faster growing of the 1950s and 1960s a little over the world, but especially in the United States, the rediscovering poverty era came up when the great intra-national inequalities became obvious. The socio-political confrontation that existed in the United States heavily influenced (qualitatively and quantitatively) the work in this subject in those decades. Harrington, for example, was a combative social democrat (or socialist?) who wanted to show the hidden poverty in America. 


\section{References}

Abbott, Edith, (1917). “Charles Booth, 1840-1916.” The Journal of Political Economy 25 (2), 195-200.

Anderson, W. H. Locke, (1964). "Trickling Down: The Relationship between Economic Growth and the Extent of Poverty among American Families.” Quarterly Journal of Economics 78 (4), 511-24.

Booth, Charles, (1887). "The Inhabitants of Tower Hamlets (School Board Division), Their Condition and Occupations”, Journal of Royal Statistical Society 5 (2), 326-401.

Booth, Charles, (1888). "Condition and Occupations of the People of East London and Hackney, 1887”, Journal of Royal Statistical Society 51 (2), 276-339.

Booth, Charles, (1903). Life and Labour of the People in London. Final Volume, London, The Macmillan Co.

Harrington, Edward M., (1962). The Other America: Poverty in the United States. New York: McGraw-Hill.

Hatton, Timothy J. and Roy E. Bailey, (1998). "Poverty and the Welfare State in Interwar London”, Oxford Economic Papers, 50, 574-606.

Hatton, Timothy J. and Roy E. Bailey, (2000). "Seebohm Rowntree and the postwar poverty puzzle”, Economic History Review, 53 (3), 517-543.

Hunter, Robert, (1902), “Book Review: Poverty: A Study of Town Life. by B. Seebohm Rowntree”, The Journal of Political Economy, 11 (1), 158-165.

Naoroji, Dadabhai, (1901), Poverty and un-British rule in India. London: S. Sonnenschein \& Co.

Rowntree, Benjamin S., (1901), Poverty: A Study of Town Life, London: Macmillan.

Rowntree, Benjamin S., (1937), The Human Needs of Labour, London: Nelson and Sons.

Rowntree, Benjamin S., and G. R. Lavers, (1951), Poverty and the Welfare State, London : Longmans, Green and Co.

Thernstrom, Stephan, (1964), Poverty and Progress: Social Mobility in a Nineteenth Century City. Cambridge: Harvard University Press. 
Townsend, Peter, (1954), “Measuring Poverty.” British Journal of Sociology, 5(2), 130-37.

Townsend, Peter, (1962), “The Meaning of Poverty”, British Journal of Sociology, 13 (3), 210-227.

Vogel, Lynn Harold, (1982), "Book Review: Poverty in the United Kingdom: A Survey of Household Resources and Standards of Living. By Peter Townsend”, American Journal of Sociology, 88 (2), 452-454.

Walker, Francis A., (1897), “The Causes of Poverty.” The Century Magazine, LV (1), 210-16.

Warner, Amos G., (1889), "Notes on the Statistical Determination of the Causes of Poverty”, Publications of the American Statistical Association, 1 (5), 183-205.

Warner, Amos G., (1894), "The Cause of Poverty Further Considered", Publications of the American Statistical Association, 4, (27), 49-68. 


\section{Tables}

Table 1: Classification of Workers in London by Charles Booth

\begin{tabular}{|l|}
\hline \multicolumn{1}{|c|}{ Classifications of Workers in London } \\
\hline The lowest class of occasional labourers, toalers, and semi-criminals \\
\hline Causal earnings; "very poor” \\
\hline Intermittent earnings; “the poor” \\
\hline Small regular earnings; "the poor” \\
\hline Regular standard earnings; above the poverty line \\
\hline Higher class labour \\
\hline Lower middle class \\
\hline Upper middle class \\
\hline
\end{tabular}

Source: Booth 1903 in Linsley and Linsley 1993

Table 2: Rowntree's 1936 poverty line for a family of five (expenditure per week)

\begin{tabular}{|l|r|r|}
\hline \multicolumn{1}{|c|}{ Expenditure } & s. & \multicolumn{1}{c|}{ d. } \\
\hline Food & 20 & 6 \\
\hline Rent & 9 & 6 \\
\hline Clothing & 8 & 0 \\
\hline Fuel and Light & 4 & 4 \\
\hline Household & 1 & 8 \\
\hline Personal & 9 & 0 \\
\hline TOTAL & $\mathbf{5 3}$ & $\mathbf{0}$ \\
\hline
\end{tabular}

Source: Rowntree (1937, p. 117) (This table uses shillings (s.) and pence (d.)). 